many of my medical brethren in this parish, of the great unfairness evidenced in the complete monopoly of all the parish appointments by Mr. Jones, would have induced me to come before the medical public in this matter; and even now I should not have done so, had it not been for feel. ing the necessity of some one interfering, as I am sorry to say that the guardians of this union, in their partiality for Mr. Jones, seem wholly to have lost sight of the ordinary principles of fairness, or they could not have given another appointment to the family of this medical pluralist.

I am, Sir, your obedient servant,
Dean-street, Soho, Aug. 1852.

To Major Graham, Registrar-General.

Dean-street, Soho, Aug. 13.

SIR,-I beg to draw your attention to what I conceive to be gross unfairness to the medical gentlemen of this parish, in an appointment to which your sanction is at present, $I$ believe, requested.

Mr. Jones, the poor-law surgeon of this parish, the surgeon to the Strand Union Workhouse, vaccinator and registrar, alarmed doubtless at the eventual results of the opposition felt by the surgeons of this parish, to his monopoly of all these offices, has made an application to the Strand Union Board, for the purpose of obtaining the appointment of deputyregistrar for his son, a young gentleman at present, $I$ believe, not of age, and a student at one of the metropolitan hospitals; the majority at the board, who are his personal friends, have acceded to his request.

The reasons, I understand, assigned for this application, are, that Mr. Jones feels that his time does not permit him to fully carry out the duties of his office.

Now, Sir, I do trust that you will not permit so great a wrong to the other surgeons of this parish to be perpetrated, knowing, as I do, that there are several to whom the emoluments arising from such an appointment would be a great boon, and that by all the rules of fairness a person who holds so many appointments ought not to have the privilege of perpetuating them in his own family.

I am, Sir, your obedient servant,

\section{J. ROGERS.}

General Registrar Office, Aug, 13, 1852

SIR,- Your letter of this day's date shall have my attention The law permits a registrar of births and deaths to appoint a fit person to be his deputy, subject to the approval of the Board of Guardians.

I have the honour to be, Sir, yours faithfully,

J. Rogers, Esq. Georan GrahaM, Registrar-General.

\section{DR. M'CORMACK'S CASE OF RUPTURED JEJUNUM. To the Editor of The LANCET.}

SIR,-I was much pleased with the very judicious and sensible remarks of your correspondent, W. U. Whitney, Esq., on the case of Ruptured Bowel, reported by me some time before. I fully agree with him that the breakfast seems to have done the mischief, and that the only chance we have in these cases is to keep the stomach free from solid food; and such was my direction to the nurse in attendance--that he was to have nothing but fluids, and that in very small quantities, until I saw him again; but it appears the unfortunate man felt himself so much better the next morning, (in fact, as he expressed himseif, "that there was nothing the matter with him,") that he disregarded my injunctions, and partook of not by any means a hearty breakfast; hence I have no doubt the fatal termination, if not actually produced, was at all events hastened. I consider it only justice to myself to state these particulars, as otherwise the remarks made by your correspondent might lead persons to imagine there had been some mismanagement in the case.

I remain yours obediently, M. J. M'Cormack, M.B., M.R.C.S.L.

Shirley, Southampton, Aug. 1852.

\section{EPIDEMIC CARBUNCULAR DISEASE.} To the Editor of THE Lancet.

Sir,-Mr. Hunt would perhaps like to know that in 184546, an epidemic of carbunculous boils prevailed in the village of Denham, near Uxbridge, a place where typhus fever used to be endemic. The poor were the sufferers. The symptoms, local and general, were severe, the latter being a modified sort of typhus. It gave me great uneasiness, as it seemed to want but a little more severity in the general symptoms to make the attack a sort of "plague."

Treatment.-Mineral acids and quinine; mercury-with-chall, and rhubarb, as an alterative; yeast to the carbuncles as a poultice. There were no cases of death.

The carbunculous boils were also common in parts of Wiltshire, in 1848-49, but not so severe; also among the poor. I have seen no fatal cases.

Latterly I have seen but few such cases, having but little to do with the poorer classes. I have noticed, however, a great increase of scrofulous abscesses of late, some of great extent and of very slow progress.

I am, Sir, your obedient servant,

Birches-green, Stroud, August, 1852.

Grorge S. Gregory.

** Instead of sending this note to Mr. Hunt, we have placed it in our columns, as it contains information which may be useful and interesting to the profession generally.Ed. Lancet.

\section{DEATH FROM HEMORRHAGE FROM LANCING THE GUMS.}

To the Editor of Tre LaNoET.

SIR,-The case of "death from hæmorrhage consequent upon lancing the gums," recorded in THE LANCET of April 24th, as having occurred to Dr. Whitworth, recalls to my remembrance a similar fatality that befel an infant under my care, many years ago.

Upon referring to my books, I find that, in October, 1838, I was requested to lance the gums of an infant four or five months of age, who was suffering from swelling and inflammation therein. I scarified them; and happening to pass the bouse about an hour afterwards, I was requested to visit the child again, as the mother informed me that the bleeding from the incision still continued. Having no styptic with me, I made use of pressure for some short time, when the bleeding seemed to be completely arrested. At about ten o'clock the same evening I was again sent for, and found that the child had suffered a rather severe loss of blood. I again resorted to pressure for some time, but without any beneficial effect; and I then cauterized the bleeding surface of the gums with the nitrate of silver; this seemed perfectly to arrest the hæmorrhage. I, however, left word that $I$ was to be sent for if anything untoward happened to my patient during the night. On riding over the following morning to see my patient, I found it on the nurse's knee, in articulo mortis, and was told that oozing from the incision had been going on most of the night; and yet they had neglected to apprise me of it, but had sent for another surgeon. What he had done I am not aware of; the child, however, died the same day.

I am afraid that such cases are not so "unique" as your correspondent seems to think; and I fear that others may have similar disasters to record.

If you think the above worthy of room in the pages of THE LANCET, I should feel obliged by your inserting it therein; and subscribe myself, Sir, your obedient servant,

South Cave, Yorkshire, 1852.

Edward des Forges.

\section{ftherical $\$$ Retos.}

Royal College of Surgeons.-At the last meeting of the Council, the following members of the College were admitted Fellows under the provisions of the recent charter:-

Atkins, J Ames Ramsex, Stoke Newington, diploma dated July 1,1825 .

Ballex, Henry Woodruffe, Thetford, Norfolk, Sept. 7, 1810

Blathwayte, William, Louth, Lincolnshire, Sept. 27, 1833.

Blenkins, George Eleazar, Whiteheads-grove, Chelsea, Oct. 7,1836 .

Blundeli, Thomas Leigh, New Broad-street, May 1, 1812.

Bossey, Peter, Woolwich, April 2, 1828.

Brown, Robert, Preston, Lancashire, Sept. 7, 1821.

Chatasse, Pye Henrt, Birmingham, Jan. 18, 1833.

Cueyne, Robert Roylex, Berners-street, Jan. 31, 1834.

Chinver, Thomas Farqumar, New Burlington-street, Oct. 17,1828 .

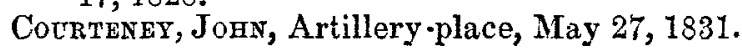

